Relations industrielles

Industrial Relations

\title{
La santé de l'ouvrier, facteur d'économie
}

\section{Wilfrid LeBlond}

Volume 1, numéro 5, janvier 1946

URI : https://id.erudit.org/iderudit/1023926ar

DOI : https://doi.org/10.7202/1023926ar

Aller au sommaire du numéro

Éditeur(s)

Département des relations industrielles de l'Université Laval

ISSN

0034-379X (imprimé)

1703-8138 (numérique)

Découvrir la revue

Citer cet article

LeBlond, W. (1946). La santé de l'ouvrier, facteur d'économie. Relations

industrielles / Industrial Relations, 1(5), 3-6. https://doi.org/10.7202/1023926ar

Tous droits réservés @ C Département des relations industrielles de l’Université Laval, 1946
Ce document est protégé par la loi sur le droit d'auteur. L'utilisation des services d'Érudit (y compris la reproduction) est assujettie à sa politique d'utilisation que vous pouvez consulter en ligne.

https://apropos.erudit.org/fr/usagers/politique-dutilisation/ 


\section{LA SANTÉ DE L'OUVRIER, FACTEUR D'ÉCONOMIE}

Répétons-le à la suite de Malcolm MacDonald et des chefs de la National Manufacturers Association : la santé de l'ouvrier est le facteur industriel le plus important, et la pire façon d'aborder ce problème serait de considérer l'organisation d'un service de santé dans une industrie comme une cuvre de simple bienfaisance ne bénéficiant pas d'un dégrèvement d'impôt.

Selon Irving Clark, l'industriel qui a organisé un service de santé dans son entreprise, le maintient non pas par philanthropie mais, parce qu'il se rend compte que la médecine préventive à l'usine est un élément de progrès, de sécurité, de prospérité dans les affaires : "Industry has adopted the Physician not from altruism but because preventive medicine practised in the factory is sound business economics, and the factory which has once established a health department has never been known to give it up ".

En d'autres termes cela veut dire que si de grandes entreprises comme l'Aluminum Company of America, la Compagnie du Téléphone Bell, l'Anglo-Canadian Pulp \& Paper, pour ne citer que quelques-unes, assurent à leurs ouvriers une surveillance médicale dès leur entrée au service de la compagnie par un examen à l'embauchage, puis par un contrôle médical des conditions de travail et de l'ouvrier au travail, ce n'est pas seulement. par altruisme. Ces compagnies ont développé et maintenu un service de santé industrielle parce qu'on s'est rendu compte que le rendement de l'ouvrier et la qualité de son travail sont en fonction de son état de santé, et des efforts qui sont faits pour assurer le bon état de cette santé. Ces compagnies et bien d'autres ont créé et, maintenu leur service de santé essentiellement parce que ça les paie.

Dans un article précédent (déc. 1945) nous avons signalé la perte de cent-vingt-cinq millions de dollars causée, en 1942, aux industriels canadiens par les maladies et les accidents du travail. Ce sont les chiffres donnés dans les Publics Health Reports de Brundage. Mais à côté de cette perte estimable il y a une autre perte incalculable : c'est la perte en rendement due aux demi-malades ; le terme est celui qui est employé par la National Manufacturers Association.

Il est assez curieux de constater que ce sont les industriels qui ont repris à leur compte le mot du célèbre hygiéniste et sociologue que fut Jules Courmont, de Lyon, pour nous rappeler qu'entre l'ouvrier en bonne santé au travail et l'ouvrier retenu à la maison par la maladie ou l'accident du travail, il y a l'ouvrier demimalade, en état de déficience physique, qui vient néanmoins au travail, et qui constitue du fait de son état de santé déficient la cause des " liabilities 》 impondérables et imprévisibles dans l'établissement d'un budget industriel ou d'une entreprise donnée. Et pourquoi?

Parce que le demi-malade, tout en ayant l'air de s'affairer comme les autres travailleurs, donne un rendement réduit en quantité et en qualité. Parce que le demi-malade est plus sujet à l'accident du travail. Nous avons constaté, personnellement, qu'une industrie possédant un service de santé a vu réduire le nombre de ses accidents du travail alors même qu'on avait supprimé par mesure d'économie (?) le service de surveillance sécuritaire. Parce que le demi-malade est, par définition, un être susceptible, un aigri qui va contribuer à grossir le contingent des mécontents chroniques qui encombrent l'agenda des séances du comité des griefs de leurs réclamations dont les plus fantastiques peuvent être à l'origine de conflits ouvriers désastreux pour une industrie. Parce que le demi-malade est souvent le porteur, le " vecteur " d'infections, de maladies latentes qui peuvent se propager sur le chantier, dans les lavabos, les vestiaires, les cantines de l'usine, chez les autres ouvriers et même chez les employeurs. Ca s'est déjà vu.

La multiplication de ces demi-malades sur un chantier ou dans une usine entraine des retards ou des diminutions de qualité dans la production. La vente du produit ouvré se faisant du manufacturier au grossiste par contrat, si ce contrat n'est pas exécuté à la date fixée le motif maladie peut servir d'explication, peut-être d'empêchement à la répudiation du contrat, mais il ne satisfait pas l'acheteur qui portera désormais ses commandes ailleurs avec les conséquences économiques que l'on sait pour les ouvriers comme pour les employeurs de l'entreprise concernée.

Et n'allons pas croire que ce sont là des vues de l'esprit, des cas hypothétiques. Ce sont des faits ; ce sont les résultats d'analyse de situations particulièrement critiques dans certaines industries contrôlées par les enquêteurs de la National Manufacturers Association (in : National Manufacturers Records in U. S. A., 1942 and 1943).

Le service de santé dans l'industrie, en plus de sélectionner la main d'œuvre, de surveiller et de maintenir son état de bonne santé, doit s'occuper particulièrement de ces demi-malades pour tâcher de les supprimer par la guérison ou tout au moins d'en diminuer le nombre.

L'organisation de l'industrie est assez standardisée pour que tous en connaissent les grandes lignes. Il y a la section ou le département de l'Administration, la section de la Production, le département de la Vente.

Cependant, aucune de ces sections ne peut fonctionner sans l'élément humain, sans un nombre déterminé d'unités-hommes au travail.

Il y a donc une quatrième section dans l'organisation industrielle, le service qui s'occupe du ravitaillement et de l'intendance de la main-d'œuvre, c'est le département du personnel.

Ce service est dirigé par un officier que l'on désigne sous le titre soit de gérant, soit de directeur du personnel. Il est responsable de l'embauchage des ouvriers, de la sélection et au besoin, comme ça s'est fait dans les industries de guerre, de la formation de la main-d'œuvre. Il doit être aussi responsable du maintien en bon état de cette main-d'œuvre, au moins au même degré que le directeur du service de la production est tenu responsable du bon fonctionnement de l'outillage.

Le directeur du personnel est donc chargé de la santé et de la sécurité des travailleurs, et c'est de lui que doit relever le service de santé dans l'industrie.

(Suite à la page 6) 


\section{L'EXTENSION JURIDIQUE}

Le prolongement normal du régime des négociations collectives obligatoires est celui de l'extension juridique. En effet, par suite de l'obligation de négocier, les conventions collectives se multiplient au point qu'avant longtemps elles couvriront pratiquement toutes les industries. Il viendra un jour où il existera dans une industrie un grand nombre de conventions collectives pratiquement identiques couvrant la majorité des travailleurs de cette industrie. Il sera alors possible d'assurer l'uniformisation des conditions de travail pour tous les ouvriers d'une même industrie. En d'autres termes le régime de l'extension juridique prendra un essor considérable.

Nous disons un essor, car le régime de l'extension juridique existe déjà. . En effet, la loi de la convention collective de la province de Québec permet l'extension juridique, depuis 1934. Ici, il importe de noter que la province de Québec occupe le premier rang dans le Dominion par sa loi d'extension juridique. Après un bref exposé du principe de cette loi, nous verrons qu'aux Etats-Unis l'on considère ce régime comme l'aboutissement normal du régime des conventions collectives.

Voyons d'abord le préambule de da loi. Il déclare : " Considérant que la justice sociale impose la réglementation du travail lorsque la situation économique entrâ̂ne pour le salarié des conditions contraires à l'équité ...." Et plus loin : "Considérant qu'il est opportun d'adopter, d'étendre et de rendre obligatoires les conditions de travail consignées dans les conventions collectives', tant pour prévenir la concurrence déloyale faite aux signataires que pour établir le juste salaire et satisfaire à l'équité :n. Comme on le constate, il s'agit de stabiliser les conditions de travail à l'intérieur d'une industrie d'uniformiser pour une certaine catégorie de tra vailleurs, les ouvriers de la chaussure par exemple, les conditions de travail. Ce principe, en plus de stabiliser les salaires, égalise les conditions de concurrence entre tous les employeurs d'une même industrie.

La meilleure façon d'expliquer ce qu'est l'extension juridique est encore de citer l'article 2 de la loi qui dit : "Il est loisible au lieutenant-gouverneur en conseil de décréter qu'une convention collective relative à un métier, à une industrie, à un commerce ou à une profession, lie également tous les salariés et tous les employeurs de la province, ou d'une région déterminée de la province, dans le champ d'application défini dans ce décret ". L'extension juridique suppose donc l'existence de plusieurs conventions collectives quasi similaires ou d'une convention couvrant plusieurs entreprises.

Mais pourquoi l'extension juridique est-elle nécessaire? Simplement pour protéger les employeurs soucieux de leurs responsabilités sociales. Il n'est que juste de les protéger contre une petite minorité qui est susceptible de leur faire une concurrence condamnable en exploitant les ouvriers. De là l'application de l'extension juridique. Notons bien que la requête d'un décret relève de l'initiative des intéressés, c'est-à-dire les signatures des conventions, les employeurs et les unions ouvrières. Après l'exécution des formalités de la loi (publication d'un avis, expiration du délai ou tenue -de l'enquête prévue), "le Ministre, s'il juge que les dispositions de la convention ont acquis une signification et une importance prépondérantes pour l'établissement des con- ditions de travail, sans grave inconvénient pouvant résulter de la concurrence des pays étrangers ou des autres provinces, peut recommander l'approbation de la requête par le lieutenant-gouverneur en conseil, avec les modifications jugées opportunes, et l'adoption d'un décret à cette fin ". C'est le décret qui déclanche l'extension juridique. Les dispositions de la convention qui deviennent obligatoires sont celles relatives au salaire, $a$ la durée du travail, à l'apprentissage et au rapport entre le nombre des ouvriers qualifiés et celui des apprentis dans une entreprise donnée. Le décret peut également rendre obligatoires les dispositions de la conventions concernant la classification des opérations et la détermination des différentes catégories de salariés et d'employeurs, ainsi que celles que le lieutenant-gouverneur en conseil estime conformes à l'esprit de la loi.

On conçoit facilement que l'application d'un décret exige un organisme compétent. C'est au comité paritaire qu'il appartient d'appliquer le décret. L'article 16 stipule que "les parties à une convention collective rendue obligatoire doivent constituer un comité paritaire chargé de surveiller et d'assurer l'observance du décret, de ses modifications et de ses renouvellements ". Ajoutons que le comité paritaire " constitue une corporation et a les pouvoirs, droits et privilèges généraux d'une corporation civile ordinaire ".

Comme on le voit, l'extension juridique est synonyme de profession organisée, c'est-à-dire, réglementation des conditions de travail de toute une profession par les intéressés, employeurs et ouvriers. A notre avis, c'est le terme de l'évolution normale des relations patronales et ouvrières:

Le régime des négociations collectives obligatoires devrait nous conduire rapidement à la multiplication des décrets. Nous avons déjà fait l'expérience de l'extension juridique et il y a lieu de croire que nous devons persister dans la même voie. D'ailleurs, si nous tenons compte des courants d'idées qui circulent aux EtatsUnis, nous sommes à l'avant-garde. C'est William $\mathbf{H}$. Davis, ex-président du National War Labor Board qui déclarait : "Industry-wide collective bargaining seems a logical next development. It makes for greater stability through out an industry, more responsible unions, and puts management on a more fair and equitable competitive basis so far as wage costs are concerned. It seems to me that what we principally need now is more organization among employer and management groups. Such organization would do much to promote an equality of bargaining power between management and labor "). Dans la province de Québec, la loi de la convention collective est l'application de ce principe et cela démontre que notre législation ouvrière ne le cède à aucune autre sur le continent américain.

L'extension juridique de la convention collective représente la formule la plus efficace d'organisation du marché du travail, tant par les employeurs que par les unions ouvrières. Elle crée un équilibre entre ces deux forces qui se rencontrent inévitablement sur le marché du travail. Elle a surtout le mérite d'être essentiellement démocratique car elle reconnait à la fois les droits et les obligations du patronat et du travail organisé.

Jean-Pierre Després. 


\section{WORKER'S HEALTH, AN ASSET IN INDUSTRY.}

" Health in Industry is a matter of crucial importance ". This statement issued by the United Kingdom Commissioner, Malcolm MacDonald, in 1942, was fully endorsed by the National Manufacturers Association.

The faultiest approach to the problem of Industrial Health would be to consider the organization of a Health program in Industry as a philanthropic gesture without even the benefit of Income Tax deduction. According to Irving Clark industry has adopted the Physician not from altruism but because preventive medicine practised in the factory is sound business economics, and the factory which has once established a health department has never been known to give it up. Even during the short time industrial medicine has been practised great advances have been made, and several medical schools have established post-graduate courses in this special line of work. The fact that industry has made substantial contributions to these post-graduate courses is the best evidence of its belief and interest in the subject.

In plain words, and with no intent to belittle the motives which have inspired such firms as the Aluminum Company of America, the Bell Telephone Company, the Anglo-Canadian Pulp \& Paper Mills and other big Corporations in organizing and developing their Industrial Health program, it is quite safe to assume that they were guided in this field less by the "Love Thy Neighbour " feeling than by the common sense which pointed out that Industrial Health actually pays its investors.

One of the great problems with which industrial health statisticians have wrestled for some time is the transmutation of the industrial health services rendered, into terms of monetary equivalents. There are both tangible and intangible returns - that is, definite benefits to which monetary values may or may not be easily assigned. Among the returns of health supervision in industry for which no financial equivalent may be assigned can be mentionned :

1. Increased production due to improvement of health standards.

2. Increased efficiency and decreased operating costs, due to fewer "occupational incompatibilities ".

3. Diminished unjust claims for compensation on the part of the malingerers, due to comprehensive records of the physical examinations of all applicants and employees.

4. Improved relations between employer and employees, due to the factor of community of interests and mutual advantages.

More than twenty years ago Dr. C. D. Selby summarized the value of health services in industry as follows :

1. The institution of a health and medical service in industry is in acknowledgement of the obligation towards the workers who sustain injuries and disease due to employment and an economical means for securing expert attention for them.

2. It is possible to remove or minimize certain causes of lost time by these methods.

3 . It stabilizes the labor-force.

4. It enables the worker to produce more.
5. It prevents litigation and reduces compensation expense.

6. It contributes to a sense of security among employees and promotes a feeling of good will towards the management.

7. In isolated establishments, it is imperative.

As to the actual financial value of an industrial health program, the survey of the National Association of Manufacturers yields some significant figures. Of the 1,625 companies which were asked if they considered the health program a paying proposition, with the exception of five all answered, "Yes ". It was stated that the five negative answers were from " independent ") plants, varying in sizes from 49 to 900 employees, and an analysis of these groups revealed that the negative responses were made with reservations, two stating that they had relatively limited services, one company having established its program only within the year, another reporting that its program was not a paying proposition, indicated that reductions had been attained in accidents, occupational diseases, labor turnover, and absences; while another company had no explanation for its negative reply. This was quoted mainly from C. O. Sappington's ; our personal experience during the last three years can be summed up in this respect in the following figures. The annual premium for Compensation based upon the accident frequency in shipbuilding industry during 1942 was $\$ 112,000,00$. In 1943, a Health program being in operation since the Spring of 1942, the actual cost of Compensation compared to the premium was $\$ 56,000.00$

\section{Factory organization :}

The object of industry is to convert crude substances into articles which can be used, and to dispose of these articles by sale. A factory purchases crude substances and by a series of machine operations produces a finished article. This process of conversion of crude subtances into finished articles is known as production. The articles produced must be sold and the business managed and financed. From this simple analysis we see that in every industry there are three great divisions, administration (which includes finance), production, and sales. Each one of these divisions is complete in itself, but each is closely allied to the others. There is, however, a fourth division which is quite separate from the other three. This division deals with personnel and its problems. It is called the personnel division. It has for its object the hiring of workers as well as maintenance of their health, safety, welfare, etc. This division includes the following departments : employment, health, visiting nurse, sanitation, safety engineering, and commissary. The personnel manager is therefore responsible for the organization of the Health Department in Industry.

\section{What are the functions of this Health Department} in industry?

1. The physical examination of all applicants for positions in the factory.
(Continued on page 6 ) 


\section{LA SANTE DE L'OUVRIER, FACTEUR D'ECONOMIE}

(Suite de la page s)

Quel est donc le rôle du service dans l'industrie?

$1^{\circ}$ L'examen des ouvriers à l'embauchage et le contrôle du placement des ouvriers qui présentent des déficiences physiques compatibles cependant avec une certaine activité physique.

L'examen périodique des ouvriers engagés à des travaux comportant un risque déterminé pour leur santé ou leur sécurité.

L'examen périodique des ouvriers qui présentaient à l'examen d'embauchage des déficiences physiques susceptibles de s'aggraver.

Un nouvel examen de l'ouvrier à chacune de şes permutations dans une autre section de l'industrie.

$2^{\circ} \mathrm{La}$ surveillance de l'état sanitaire général des locaux de travail et des annexes : vestiaires, cantines, lavabos.

La surveillance de l'application des mesures sanitaires spéciales à l'industrie concernée.

$3^{\circ}$ L'organisation et la surveillance d'un service de premiers soins aux blessés et aux malades. L'organisation du service de l'enseignement du secourisme aux ouvriers.

L'inculcation de la notion du safety consciousness aux ouvriers.

$4^{\circ}$ La diffusion parmi les travailleurs des lois fondamentales de l'hygiène générale : alimentation, vêtement, sanitation individuelle, vie bien ordonnée, prévention des maladies vénériennes ; connaissance des règles précises de l'hygiène industrielle dans le cas de travaux comportant des risques particuliers pour la santé ou la sécurité du travailleur.

Dans un autre article nous étudierons le mode d'organisation et le fonctionnement d'un tel service de santé dans l'industrie.

Docteur Wilfrid LeBlond, chargé de cours d'Hygiène industrielle à l'Université Laval, Québec.

\section{WORKER'S HEALTH, AN ASSET IN INDUSTRY}

(From page 5)

2. The re-examination of all employees transferred from one department to another.

3. The periodic examination of workers employed in departments where there is a health or safety hazard.

4. A periodic examination of all workers who have physical defects needing follow-up.

5. The placing of physically defective workmen in departments where the work will not prove imjurious.

6 . The diagnosis, and in certain cases, the treatment of workers applying to the dispensary for medical care.

Cooperation, where possible, with the family physician of sick and defective employees.

7. Diagnosis and treatment of workers injured during employment.

8. Diagnosis and in some cases treatment of workers having surgical conditions not the result of employment.

9. Visiting and assisting workers who are absent from work because of accident and sickness from any cause whatever.

10. Controlling all factory sanitation.

11. Organization of first-aid training among employees.

12. Spreading of health publicity : nutrition, personal hygiene.

Venereal disease prevention, etc, by lectures, leaflets and best of all through a shop or plant Bulletin or other publication. The medical department acts as a health center for the factory, its personnel consisting of the chief physician and his assistants and nurses. It is in

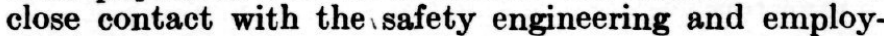
ment departments.

How to organize and operate such a department will be discussed in a following paper.

WILFrid LeBLOND, M.D., Professor of Industrial Hygiene, Laval University, Quebec.

\section{CLAUSES D'ATELIER SYNDICAL ET D'ATELIER FERME}

(Suite de la page \&)

être membres en règle du syndicat. Ceux qui ne le seraient pas actuellement devront le devenir dans les trente jours qui suivront la date de l'entrée en vigueur de la présente convention.

L'employeur s'engage, pour toutes les catégories de travailleurs couverts par cette convention, (ou bien pour telle catégorie particulière), à n'embaucher que des membres en règle du syndicat, pourvu, toutefois, que ces travailleurs soient disponibles et ajent la compétence nécessaire. $\mathrm{Si}$, dans une période de trois (ou bien six, dix) jours, le syndicat ne présente pas un candidat possédant les qualifications requises, l'employeur est dégagé de cette obligation, mais l' nouveau travailleur qu'il embauchera devra s'affilier au syndicat dans les trente (soixante ou quatre-vingt dix) jours qui suivront la date de son entrée au service de l'employeur.
$\mathrm{Si}$ un travailleur cesse son adhésion au syndicat pendant la durée de la présente convention; le secrétaire du syndicat en donnera avis, par écrit, à l'employeur et celui-ci devra, dans les dix (ou quinze) jours suivants, mettre fin à l'emploi de ce travailleur. Nous ne croyons pas que les cadres de cette revue nous permettent d'entrer dans des détails supplémentaires. Et l'on voudra bien remarquer que nous ne prenons pas ici position en faveur d'une clause plutôt qu'une autre et que nous n'avons porté aucun jugement pratique sur leur légitimité ni leur opportunité. Nous nous sommes borné à exposer aussi clairement et aussi objectivement que possible les distinctions qui s'imposent, afin d'éclairer les employeurs et les employés. Libre à eux de juger s'ils doivent ou non inclure de telles clauses dans les conventions qu'ils auront l'occasion de négocier.

Ggrard Dion. 